Annals of Warsaw University of Life Sciences - SGGW

Land Reclamation No 48 (1), 2016: 53-65

(Ann. Warsaw Univ. Life Sci. - SGGW, Land Reclam. 48 (1), 2016)

\title{
Analysis of the multistage cyclic loading test on resilient modulus value
}

\author{
WOJCIECH SAS ${ }^{1}$, ANDRZEJ GŁUCHOWSKI르, EMIL SOBÓL ${ }^{2}$, \\ JACEK BĄKOWSKI ${ }^{1}$, ALOJZY SZYMAŃSKI ${ }^{2}$ \\ ${ }^{1}$ Water Centre Laboratory \\ ${ }^{2}$ Department of Geotechnical Engineering \\ Warsaw University of Life Sciences - SGGW
}

\begin{abstract}
Analysis of the multistage cyclic loading test on resilient modulus value. Upon cyclic excitation of soil mass, two types of strain can be recognized, namely elastic and plastic one. Proper analysis of these two types of deformations can help engineers in designing more reliable structures. In this study, a multistage uniaxial cyclic loading in unconfined conditions was performed. Tests were performed in order to characterize strain response to repeated excitation. Soil sample under cyclic loading was recognized as exhibiting the symptoms of a plastic strain growth during the cyclic loading process with exponential manner, when compared to number of cycles. Soil in this study was reconstituted and compacted by using the Proctor method to simulate conditions similar to those affecting the road subbase. The soil was recognized as sandy clay. Results were analysed and a proposition of empirical formula for plastic strain calculation with the use of characteristic stress values was presented. The resilient modulus values were also calculated. The $M_{r}$. value was within range from 45 to $105 \mathrm{MPa}$. The conclusions concerning the cyclically loaded soil in uniaxial conditions were presented.
\end{abstract}

Key words: cyclic loading, resilient modulus, cohesive soil, uniaxial compression tests, plastic strain

\section{INTRODUCTION}

Behaviour of soils subjected to cyclic loading in road engineering is an important subject of studies. Nowadays, many propositions for predicting permanent strain development are being presented (Werkmeister 2006). Some of them are based on the value of the resilient modulus and more extensive studies lead to the introduction of the shakedown theory for unbound granular materials.

According to Mechanistic Empirical Design Guide (MEPDG), 1993 AASHTO flexible pavement design guide, or Eurocode PN-EN 13286-7:2004, resilient modulus is presented as a key material property in the structure design of pavement.

Structure of pavement basically consists of layers. One of those is the subgrade, which usually is comprised of cohesive soils. One of best known stiffness parameters describing the subbase and subgrade materials is the resilient modulus $\left(M_{r}\right)$. The term resilient modulus is borrowed from the elastic theory, although subgrade materials themselves are not elastic. Nevertheless, if the load is small enough during large number of repetitions the soil can behave in nearly elastic manner where the deformation is nearly fully recoverable (Gluchowski et al. 2015). 
Besides many factors, which have impact on road structure performance, such as kinds of materials being used, climatic conditions, capillary water or construction method, which are the scope of many studies, the response of subgrade under cyclic loading seems to be neglected.

Well-designed structure of road implies low stress level in the subgrade, therefore in this case, proper chemical stabilization is enough to prevent the occurrence rutting phenomena.

In case of low cost- or temporary road infrastructure, chemical stabilization could exceed the investment budget. On the other hand, designers are still obliged to provide high quality and good performance of the road.

Moreover, this type of infrastructure is usually placed in locations characterised by complex conditions, for example in reclaimed rural areas. Subgrade cohesive soils are subjected to changing conditions, for example moving water table, which causes changes in strength of this material.

Cyclic excitations applied to subgrade under such conditions may result in excessive permanent strains which could lead to the road's failure when the cyclic load cross ratcheting limit.

For better understanding of the cohesive soil behaviour under cyclic loading in subgrade layer, tests under low confining pressure have been be performed.

\section{LITERATURE REVIEW}

Requirements regarding parameters for road design are still under development. Offshore geotechnical engineering and foundation designers also seek for material characteristics under cyclic excitation (O'Reilly and Brown 1991, Sas et al. 2014, Lavasani et al. 2015).

Applied stress causes a development of elastic and plastic strains in soils. In small strain range, the effects of strains are almost fully recoverable. When stress value crosses the level of yield stress characteristic for each material, a plastic strain occurs. The impact of plastic response of porous media on the structures is included when serviceability limit state is assessed. The plastic deformations may be observed even in small stress range, therefore the proper study of this occurrence is needed (Uzan 2004, Wu and Chen 2010, Sas et al. 2014).

Cyclic loading phenomenon was studied in numerous papers, most of them concerning conditions under which tested material would undergo failure. Nevertheless, most of the constructions fail not due to collapse, but simply because of over-settlement in foundation engineering or rutting, in case of road engineering, caused by permanent strain (Srinivasulu and Vaidyanathan 1976 Randolf and Gouvernec 2011, Tafreshi and Mehrjardi 2011).

Beside natural events, such as earthquakes or sea waves, which cause repeated loadings, cyclic excitations are caused by human activity and are characterised by varying amplitudes of loading. Type of loading, which can be in the form of sinusoidal, triangular or trapezoidal wave, also seems to impact the strain development (Pecker 2007, Sas and Głuchowski 2013a, b). 
Plastic behaviour of soil under cyclic loading leads to an increase of plastic strain, but its development varies, depending on the range of applied cyclic stress levels. Shakedown theory in soil mechanics assumes three ways of possible behaviour. If applied stress level is low enough, plastic strain increment stops, which can be noted after a large number of cycles.

The results of investigations conducted on cohesive soil, which was loaded cyclically in one dimensional consolidation conditions, have led to the conclusion that the shape (period of loading cycle if time needed to reach maximum stress) of the loading cycle (time needed to reach maximal stress) has an impact on strain development during loading. Moreover, in case of loading having the trapezoidal shape, the displacement rate was the greatest during the end of loading phase and the lowest during the end of the unloading phases, respectively (Zhuang 2005, Wu and Chen 2010).

The cyclic loading in soil media results in the plastic strain increment with a number of the cycles which can be dependent on many factors, such as the stress amplitude and stress level. In opposition to static loading of the soil, where failure is considered, repeated loading can lead to failure, because of excessive strain for stress levels lower than those observed during failure in undergoing static tests (Werkmeister 2001, 2006, Whitman and Richart 2005).

Soils can exhibit different responses to cyclic loading in case of cohesive and non-cohesive soils. In cohesive soils, liq- uefaction phenomenon does not occur, but in both cases, pore pressure increment still has an impact on soil response during the undrained triaxial tests (Sawicki and Świdziński 1989, Głuchowski et al. 2015).

During extensive studies on the plastic strain development caused by repeated loading, a number of soil behaviour phenomena were noticed. It was observed that after numerous cycles, plastic strain increment tends to decrease down to zero during drained tests. This phenomenon was similar to the shakedown event during extension tests on metals. Shakedown explains possible response of soil to cyclic loading. Plastic shakedown will occur, if the level of stress is low enough. At this stage, plastic strain rate decreases during the cyclic loading. However, unlike in metal bars, plastic strains will not vanish completely. If cyclically acting stress crosses threshold stress limit, a cyclic creep will appear. At this stage, plastic strains are observed in each cycle and soil will eventually fail due to excessive total plastic strain. Plastic strain increment is usually presented in the form of a graph versus a number of cycles and it can represent rut depth development (Whitman and Richart 2005, Tafreshi and Mehrjardi 2011).

One of the key parameters referring to cyclic loading in soil mechanics is the resilient modulus. Resilient modulus describes the amount of elastic strain during unloading under cyclically acting stress (Brown 1996, Tao et al. 2010).

Figure 1 presents in a schematic way the development of strains during a sin- 
gle cycle of loading. Resilient modulus value can be obtained from uniaxial or triaxial tests. Equation (1) is employed to calculate the $M_{r}$ value:

$$
M_{r}=\frac{\sigma_{d}}{\varepsilon_{r}}
$$

where:

$\sigma_{d}-$ deviator stress,

$\varepsilon_{r}-$ elastic strain.

Deviator stress calculated as:

$$
\sigma_{d}=\frac{P}{A}
$$

where:

$P$ - force, $A$ - area of sample.

Elastic strain is calculated as:

$$
\varepsilon_{r}=\frac{\Delta H_{r}}{H_{i}}
$$

where:

$\Delta H_{r}$ - elastic displacement, $H_{i}$ - height of sample.

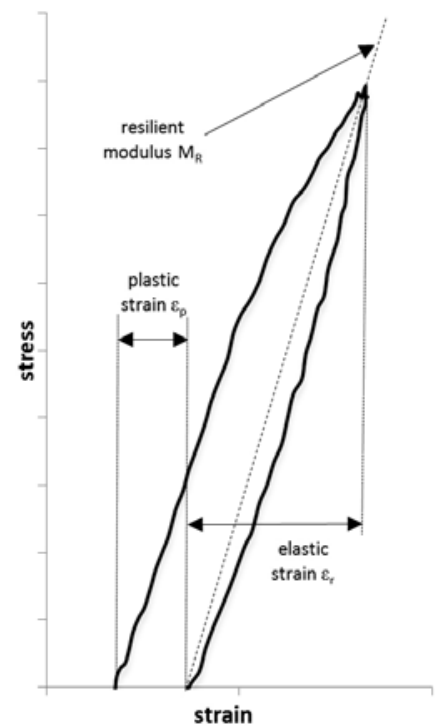

FIGURE 1. Schematic redistribution of strains during one loading cycle of soils

\section{MATERIAL}

Material in this study was classified on the basis of a sieve analysis as sandy clay $(\mathrm{saCl})$, in accordance with Eurocode 7 PN-EN 1997-2:2009. Figure 2a presents the results of the above-mentioned test. The material was taken from a road construction site. Figure $2 b$ presents the results of a Proctor's test using standard energy of compaction, which equals $0.59 \mathrm{~J} / \mathrm{cm}^{3}$ (PN-88/B-04481). Optimal moisture content amounts to $10.3 \%$ and dry density is equal $2.17 \mathrm{~g} / \mathrm{cm}^{3}$. Liquid limit obtained from a Casagrande test was equal $20 \%$.

a

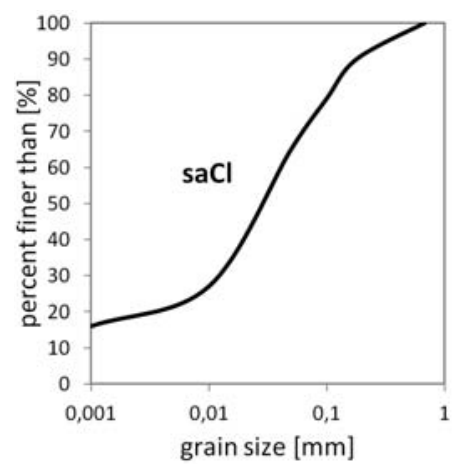

b

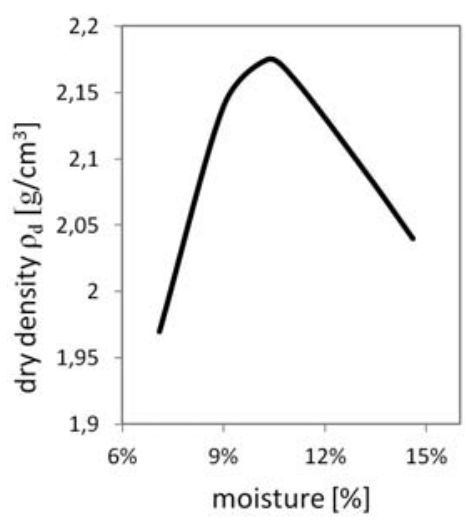

FIGURE 2. Gradation curve of tested soil (a), results of optimal moisture on the basis of Proctor's test (b) 


\section{METHODS}

The cyclic triaxial compression test (cyclic unconfined uniaxial compression test) was conducted with no cell pressure (unconfined conditions). Sample was kept in optimal moisture content. Height of sample was $140 \mathrm{~mm}$ and its diameter was equal $70 \mathrm{~mm}$. Test was consisted of eight series of cyclic loading. Unconfined triaxial compression test was performed in a one-way manner. Each series of cyclic excitations was performed with an amplitude of loading equal $11 \mathrm{kPa}$. Frequency in this study was equal $0.1 \mathrm{~Hz}$, while the number of cycles was equal 100.

The main purpose of this test was to characterize the behaviour of compacted cohesive soil during cyclic loading. The strain development prediction is associated with a proper classification of soil response to cyclic loading. From a practical point of view the behaviour of soil in such deformation range is important for the proper design of constructions. The cyclic loading test stages were divided into a series of steps characterised by increasing loads, which may occur during the construction phase. For the purposes of this paper, the issue of cyclic loading was simplified to sinusoidal loads of low frequency. Maximal stress during a single stage was equal $\sigma_{1, \max }=$ $=57.8 \mathrm{kPa}$ and minimal stress was equal $\sigma_{1 . \min }=48.3 \mathrm{kPa}$. After this stage, the unloading process was performed, during which the following values were controlled: $\sigma_{1 \text {.max }}=16.0 \mathrm{kPa}$ and $\sigma_{1 . \min }=5.4 \mathrm{kPa}$. The last stage of this test was loading to $\sigma_{1 . \text { max }}=68.3 \mathrm{kPa}$ and $\sigma_{1 \text { min }}=57.8 \mathrm{kPa}$. Such values of stress were adopted in order to characterise the resilient modulus and plastic strain development. The assumed stress conditions were depended from test method, where $\mathrm{s}$ in $\mathrm{kN}$ units. The multistage test manner was performed in order to obtain possible change of soil behaviour in respect to shakedown theory. The applied stresses were in the range of 10 to $70 \mathrm{kPa}$ and included the average stress of traffic load at a depth of $0.5 \mathrm{~m}$.

This procedure of a multistage cyclic loading was performed in order to describe the behaviour of cohesive soils under a decreasing cyclic stress. After 100 repetitions under a lower stress level, soil was again loaded, by applying a greater stress level, which exceeded the one applied during the first stage. The response of the material was later presented with the use of a stress-strain plot.

\section{RESULTS}

In Figure 3, the results of a uniaxial cyclic test on soil sample, which was cyclically loaded and unloaded, are presented. The test was divided into two phases. The multistage loading phase was the first one. The first five stages of loading were characterised by an average stress level of $\sigma_{1 \text { avx }} \approx 10.5 \mathrm{kPa}$. The sixth phase consisted of unloading under stress conditions identical to those present during the first stage of multistage loading. At the end of the test, loading was performed as for the sixth stage of multistage loading. The cyclic stress amplitude drop dur- 


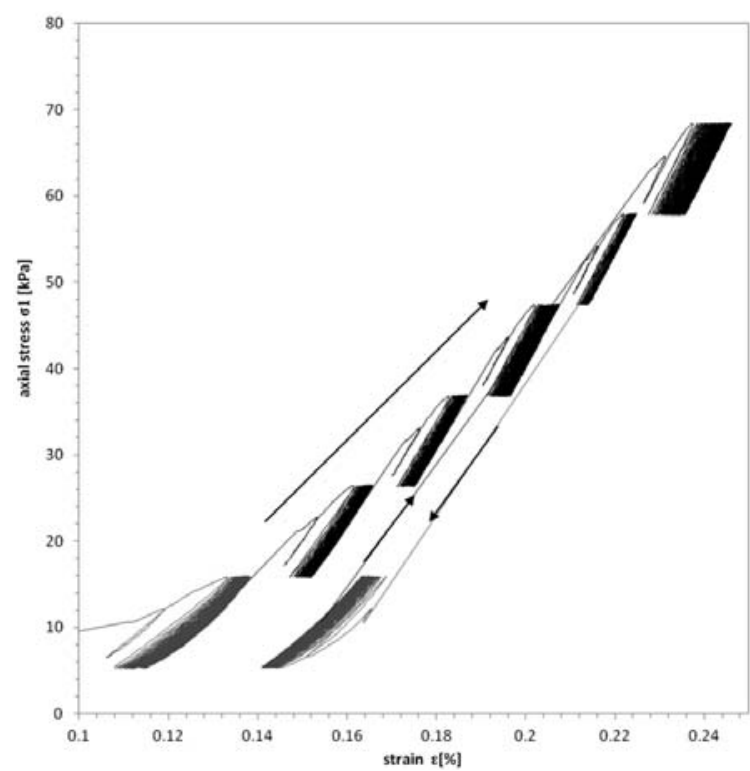

FIGURE 3. Plot of axial stress $\left(\sigma_{1}\right)$ and strain $(\varepsilon)$ in unconfined cyclic loading test

ing the sixth stage is characteristic for the repeated loading phenomenon not only under a constantly increasing stress level amplitude, but also after a partial decrease of the cyclic stress.

During Stage 5, the initial strain level was equal $0.21 \%$. The next 100 cycles caused an increase of plastic strains, which was equal $0.0032 \%$. During Stage 6, the unloading to stress range in first phase was performed. Unloaded soil specimen responded with an elastic strain in first cycle, which was equal $0.00782 \%$. During the following cycles, sandy clay also responded to loading by exhibiting an elastic strain. The difference between the first and the last strain value was equal $0.0046 \%$. After the sixth phase of loading, the Stage 7 of the multistage programme was carried out. Increase of plastic strains during cyclic loading in Stage 7 is greater than the in- crease of plastic strain in Stage 5. This phenomenon is caused by a decreasing load range during the sixth phase.

Figure 4 presents the change of strains in time for Stages 5, 6 and 7. An increase of axial stress causes the plastic strain to occur during Stage 7 of loading. During Stage 5, the strain seems to decrease, as it does in Stage 6. During the second phase of loading, the plastic strain increment stabilised at level near to zero. During the third phase of loading in the fifth stage, the strains begin to decrease. This phenomenon is caused by the shakedown of the sample and the multistage manner of testing. The shakedown theory states that if axial stress is low enough, the plastic strain increment decreases to a point, in which very minor or no plastic strain occurs during a single cycle. Multistage cyclic loading caused high accumulation of elastic en- 


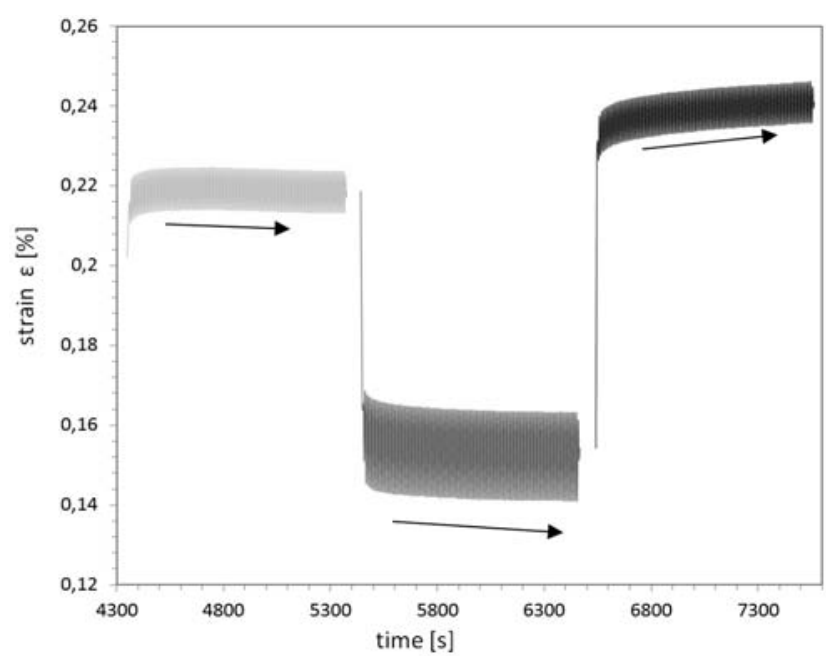

FIGURE 4. Plot of strain $\varepsilon$ time change in cyclic uniaxial cyclic compression test, loading Stages 5,6 and 7

ergy. After the fifth stage, the specimen was unloaded to a lower stress level, recovering $27 \%$ of strain at the end of Stage 5. The backward movement of stress-strain relationship is caused by the consolidation phenomenon. The strain reversal therefore was observed in lower stress amplitude. The increase of stress level, while the soil was in plastic shakedown state, caused the irrecoverable strain accumulation to occur again during the first stage of loading. Shakedown theory for soils states that plastic strains never vanish completely. Nevertheless, the complete unloading down to zero was not conducted during this study but minimal stress in every stage of loading was maintained.

In Figure 5, the detailed view of the first $50^{\text {th }}$ and $100^{\text {th }}$ cycle was presented for stages 5, 6 and 7 of repeated loading. During Stage 5, as was mentioned before, the strain obtained at the $100^{\text {th }}$ cycle was smaller than the one obtained at the $50^{\text {th }}$ cycle. During Stage 6 , the strains stops to accumulate. The difference between maximal strain during the Stage 5 and minimal strain during the Stage 6 was $0.0827 \%$. It means that the elastic strain between these two stages constitutes $36 \%$. In this stage, wedged particles released its cumulated elastic energy. During Stage 7, the increase of plastic strains was greater, when compared to Stage 5 and no strain reversal phenomenon was observed. This occurrence was caused by the major loss of the elastic energy accumulated in the soil specimen. The higher axial stress level led to the accumulation of plastic strains and subsequent rearrangement and wedging of particles in the soil skeleton.

Figure 6 presents the results of the resilient modulus calculation. In case of Stages 4, 5 and 7, the obtained $M_{r}$ level was the highest and reached $103 \mathrm{MPa}$. Those values are close to each other, even after the increase of plastic strain 

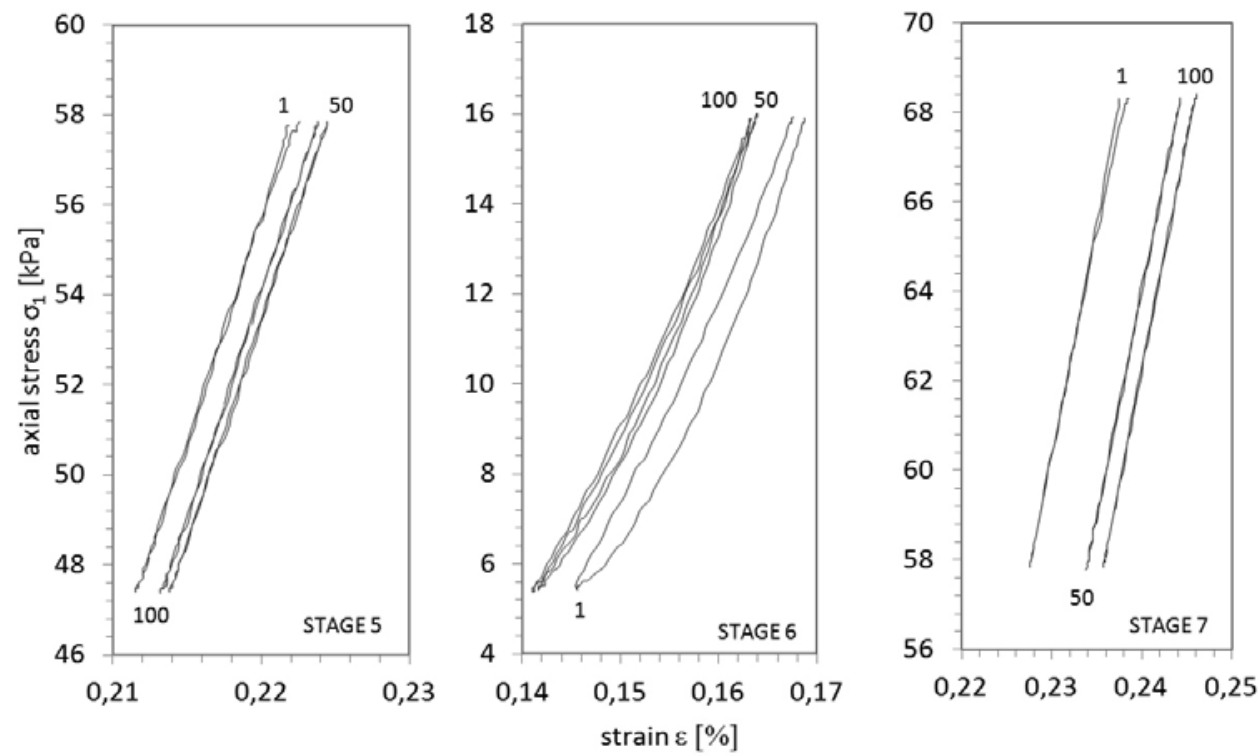

FIGURE 5. Plot of strain $(\varepsilon)$ change due to acting axial stress $\left(\sigma_{1}\right)$ during cyclic uniaxial compression test for Stages 5, 6 and 7 for cycles 1, 50, 100

observed during Stage 7 and the previous phase of unloading. The unloading phase is similar to the first stage of the multistage test. The unloading stage leads to a stiffer response at the beginning of Stage 7 , which occured along with the increase of the resilient modulus value (Fig. 6). During the subsequent cycles at Stage 7, the resilient modulus has decreased and after 100 load repetitions the $M_{r}$ value was equal to the resilient modulus at the end of Stage 5.

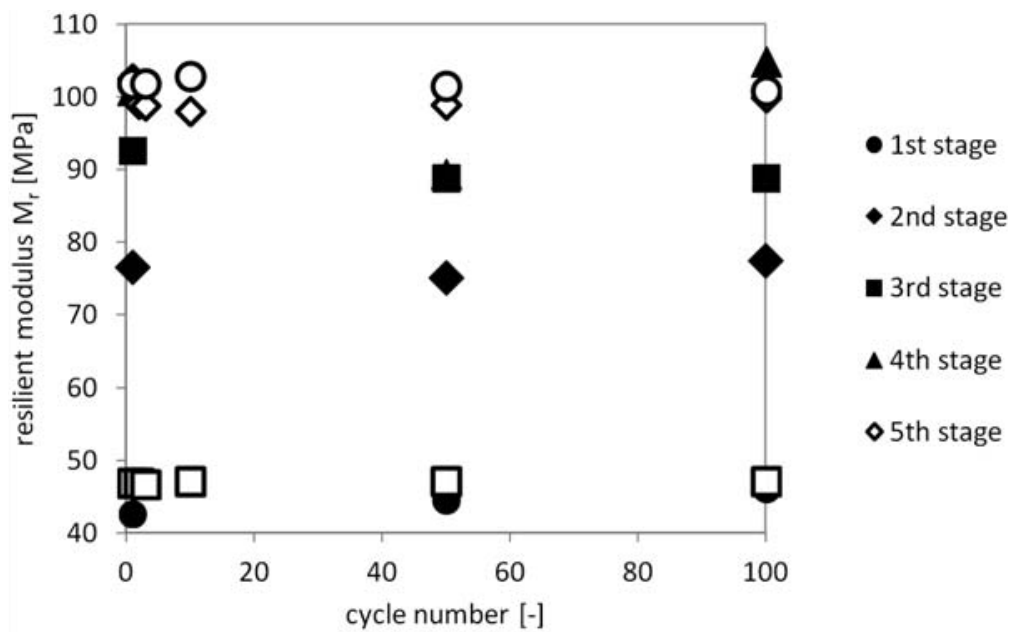

FIGURE 6. Plot of resilient modulus $\left(M_{r}\right)$ calculation in next cycles of cyclic multistage test 
The resilient modulus also express the development of elastic strains in each stage. During cyclic loading we can observe different responses of cohesive soil to stress reference levels. During Stages 1 and 2, the resilient modulus value rises with each cycles, so we can observe the of stress reference levels, the resilient modulus value also grows.

In Figure 7, a plot of plastic strain change versus the number of cycles is presented. The plastic strain change clearly has exponential growth. For the first five stages, the function of the plas-

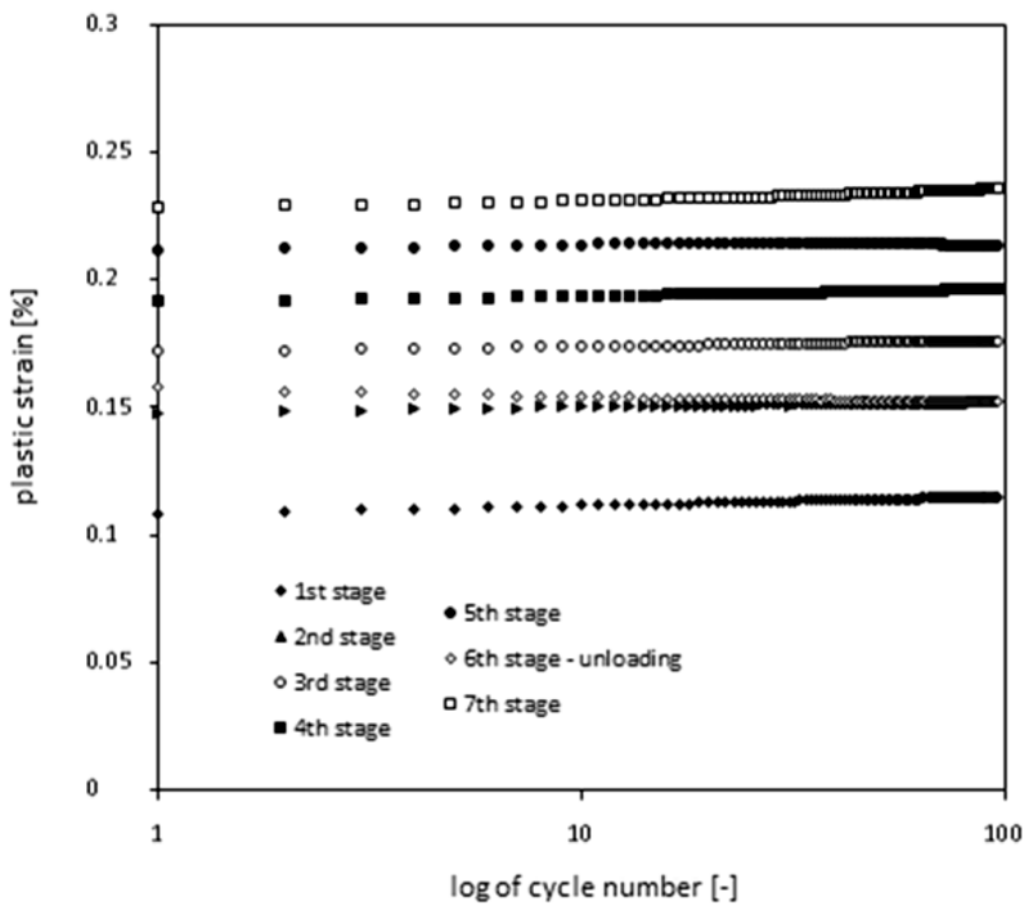

FIGURE 7. Plot of plastic strain versus log of number of cycles for tested soil

rise of sample stiffness (Figs 3 and 6). In case of Stage 3, a different response can be observed. The resilient modulus value decreases, which results in the loss of stiffness. The same phenomenon can be observed during Stage 4. Until the $50^{\text {th }}$ cycle, the $M_{r}$ value decreases, but rises again after reaching that point. It is important to note that after the increase tic strain change in the following cycles was calculated on the basis of the standard exponential equation (4):

$$
\varepsilon_{p}=a \cdot N^{b}
$$

where:

$a$ - plastic strain after first cycle,

$N$-number of cycle,

$b$-empirical parameter. 
The $a$ and $b$ parameters for five stages are presented in Table 1.

TABLE 1 . The parameters $a$ and $b$ for plastic strain - number of cycles relationship

\begin{tabular}{|c|c|c|}
\hline Stage & $a$ & $b$ \\
\hline 1 & 0.108 & 0.0136 \\
\hline 2 & 0.1475 & 0.0073 \\
\hline 3 & 0.1716 & 0.005 \\
\hline 4 & 0.1916 & 0.0055 \\
\hline 5 & 0.2117 & 0.002 \\
\hline
\end{tabular}

The impact of deviator stress can be distinguished in the form of characteristic values presented in Figure 8.

The values of $S_{a}, S_{m}, S_{\text {min }}$ and $S_{\text {max }}$ are presented in details in Table 2. For the calculation of plastic strain in varying deviator stress conditions, the relation- ship between the parameter $b$ and characteristic stress values was established.

TABLE 2. The parameters of stress characteristic values

\begin{tabular}{|c|c|c|c|c|}
\hline Stage & $S_{m}$ & $S_{a}$ & $S_{\min }$ & $S_{\max }$ \\
\hline 1 & 53 & 27 & 26 & 80 \\
\hline 2 & 105 & 26 & 79 & 131 \\
\hline 3 & 157.5 & 26.5 & 131 & 184 \\
\hline 4 & 208.5 & 24.5 & 184 & 233 \\
\hline 5 & 260.5 & 24.5 & 236 & 285 \\
\hline
\end{tabular}

The equation which leads to estimating the $b$ value is as follows:

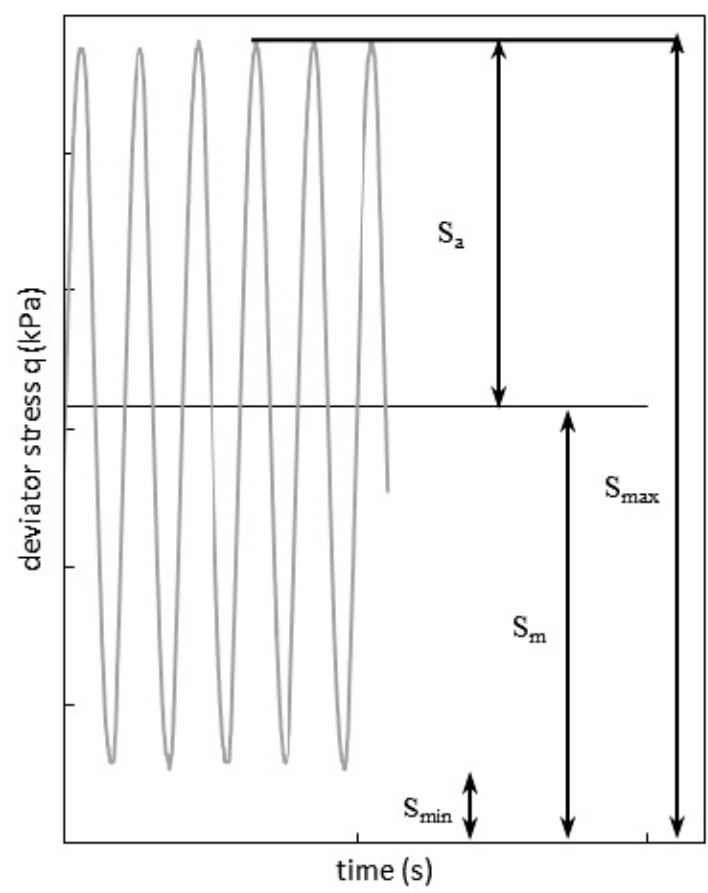

FIGURE 8. Plot of deviator stress characteristic values 
The coefficient of determination $\left(R^{2}\right)$ for this relationship is equal 0.967 . Based on Equation (5), the estimation of plastic strain for Stages from 2 to 4 was performed. The results are presented in Figure 9. The calculated plastic strain versus number of cycles shows good agreement with the test results. The
1. Sandy clay is a material, which in low stress range can undergo shakedown and therefore a decrease of plastic strains during multistage cyclic loading test is observed.

2. In accordance with the shakedown theory, the plastic shakedown occurred in the tested sample.
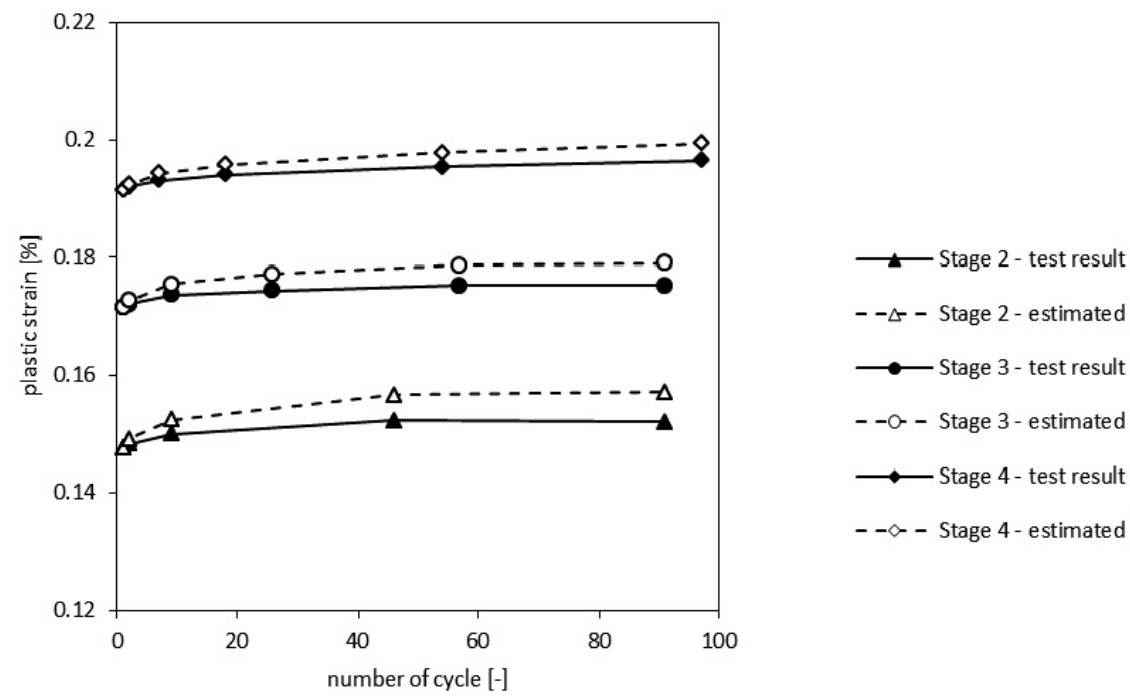

FIGURE 9. Plot of plastic strain obtained from test results and calculations for multistage cyclic uniaxial unconfined tests

stress amplitude $\left(S_{a}\right)$ and stress median $\left(S_{m}\right)$ parameters can be used to calculate the plastic strain and to calculate possible plastic deformations under varying stress conditions.

\section{CONCLUSIONS}

The cyclic unconfined uniaxial compression test conducted on unsaturated sandy clay led to the following conclusions:
3. The strain reversal at constant stress amplitude in Stage 5 was observed.

4. Resilient modulus is a parameter describing elastic response during unloading phase of the cyclic loading. Between the unloading phase (Stage 6 ) and the first loading phase (Stage 1) and loading phases at Stages 5 and 7 , similar values of resilient modulus were observed, which were equal 45 and $105 \mathrm{MPa}$ respectively. This phe- 
nomenon confirms the impact of deviator stress on strain characteristic of soil.

5. Multistage cyclic loading is characterised by the compressibility of cohesive soils, which is similar to standard results of consolidation. After unloading phase (Stage 6), the strain reversal was observed.

6. The deviator stress characteristic values obtained from the cyclic unconfined uniaxial compression test were utilised to calculate plastic strains. Equations (4) and (5) can be utilised to calculate plastic deformations in uniaxial conditions.

\section{REFERENCES}

BROWN S.F. 1996: 36th Rankin Lecture: Soil mechanics in pavement engineering. Géotechnique 46 (3), 383-426.

GŁUCHOWSKI A., SZYMAŃSKI A., SAS W. 2015: Repeated Loading of Cohesive SoilShakedown Theory in Undrained Conditions. Studia Geotechnica et Mechanica, 37 (2), 11-16.

LAVASANI M., NAMIN M.L., FARTASH H. 2015: Experimental investigation on mineral and organic fibre effect on resilient modulus and dynamic creep of stone matrix asphalt and continuous graded mixtures in three temperature levels. Construction and Building Materials 95, 232-242.

O'REILLY M.P., BROWN S.F. 1991: Cyclic loading of soils. Blackie and Son, London.

PECKER A. 2007: Advanced Earthquake Engineering Analysis. Springer, New York.

RANDOLPH M., GOUVERNEC S. 2011: Offshore Geotechnical Enigineering, Edition. Spon Press.

SAS W., GŁUCHOWSKI A. 2013a: Application of cyclic CBR test to approximation of subgrade displacement in road pavement. Acta
Scientarum Polonorum, Architectura 12 (1), 51-61.

SAS W., GŁUCHOWSKI A. 2013b: Predicting the type and size of soil strain due to cyclic loading with plastic-displacement model. Acta Scientarum Polonorum, Architectura 12 (3), 135-147.

SAS W., GABRYŚ K., GŁUCHOWSKI A., SZYMAŃSKI A. 2014: The influence of dynamic loading on Road pavement construction and associated Road structures. XV Danube - European Conference on Geotechnical Engineering 1, 107-112.

SAWICKI A., ŚWIDZIŃSKI W. 1989: Pore pressure generation, dissipation and resolidification in a saturated subsoil. Soils and Foundations 29 (4), 62-74.

SRINIVASULU P., VAIDYANATHAN C.B. 1976: Handbook of Machine Foundations. Tata McGraw-Hill, New Delhi.

TAFRESHI G.T., MEHRJARDI S.N.M. 2011: Experimental and numerical investigation on circular footing subjected to incremental cyclic loads. International Journal of Civil Engineering 9 (4), 265-274.

TAO M., MOHAMMAD L., NAZZAL M., ZHANG Z., WU Z. 2010: Application of Shakedown Theory in Characterizing Traditional and Recycled Base Materials. ASCE Journal of Transoprtation Engineering 136 (3), 214-222.

UZAN J. 2004: Permanent deformation in flexible pavements. Journal of Transportation Engineering 130, 1, 6-13.

WERKMEISTER S. 2001: Permanent deformation behaviour of granular materials and the shakedown theory. Journal of Transportation Research Board 1757, 75-81.

WERKMEISTER S. 2006: Shakedown analysis of unbound granular materials using accelerated pavement test results from New Zeland's CAPTIF facility. Geotechnical Special Publication 154, 220-228.

WHITMAN R.V., RICHART F.E. 2005: Design Procedures for Dynamically Loaded Foundations. Journal of the Soil Mechanics and Foundations Division 93 (6), 169-193.

WU Z., CHEN X. 2010: Finite element sensitivity analysis of permanent deformation under ac- 
celerated loading. Proceedings of GeoFlorida - Advances in Analysis, Modeling \& Design, West Palm Beach, Florida.

ZHUANG Y., XIE K. 2005: Study on one-dimensional consolidation of soil under cyclic loading and with varied compressibility. Journal of Zhejiang University 6A (2), 141-147.

PN-EN 1997-2:2009. Eurokod 7. Projektowanie geotechniczne. Część 2: Rozpoznawanie i badanie podłoża gruntowego [Eurocode 7 . Geotechnical design. Part 1. Ground investigation and testing].

PN-88/B-04481. Grunty budowlane. Badania próbek gruntu. [Types of ground. Laboratory tests on soils].

Streszczenie: Analiza wpływu wieloetapowego cyklicznego obciqżenia na wartość cyklicznego modułu sprężystości. Odkształcenia powstające podczas obciążenia cyklicznego w jednym cyklu składają się z odkształceń sprężystych i plastycznych. Właściwe rozpoznanie zjawiska ich zachowania się pod obciążeniem cyklicznym może być pomocne dla inżynierów w trakcie projektowania budowli. W artykule przedstawiono wyniki badań cyklicznego jednoosiowego ściskania. Badania te zostały przeprowadzone w celu ustalenia reakcji gruntu spoistego na obciążenia cykliczne. Badany grunt wykazał akumulację odkształceń plastycznych, których wzrost miał charakter wykładniczy. Badania symulowały obcią- żenie cykliczne powstające w wyniku przejazdu pojazdów, $\mathrm{z}$ tego powodu też grunt użyty $\mathrm{w}$ tym badaniu był zagęszczony metodą Proctora. Grunt rozpoznano jako ił piaszczysty. Wyniki badań poddano analizie, która pozwoliła na ustalenie empirycznej zależności przyrostu odkształceń plastycznych na podstawie charakterystycznych wartości dewiatora naprężenia. Ponadto ustalono wartości cyklicznego modułu sprężystości $\left(M_{R}\right)$. Maksymalna wartość cyklicznego modułu sprężystości wynosi $105 \mathrm{MPa}$, a minimalna $45 \mathrm{MPa}$. Praca zakończona jest wnioskami dotyczącymi wyników badań gruntu spoistego obciążonego jednoosiowo.

Stowa kluczowe: obciążenia cykliczne, cykliczny moduł sprężystości, jednoosiowe ściskanie, odkształcenia plastyczne

\section{MS. received February 2016}

\author{
Authors' address: \\ Wojciech Sas \\ Laboratorium Centrum Wodne \\ ul. Ciszewskiego 6, 02-776 Warszawa \\ Poland \\ e-mail: wojciech_sas@sggw.pl \\ andrzej_gluchowski@sggw.pl \\ emil_sobol@sggw.pl \\ jacek_bakowski@sggw.pl \\ alojzy_szymanski@sggw.pl
}

